УДК 811.133.1’255.4 (045)
DOI 10.35433/philology.1(89).2019.75-80

\begin{abstract}
А. С. Кузнєцова, асистент

(Київський національний університет культури і мистецтв) serhienko14@gmail.com ORCID: 0000-0001-8668-8456

Ю. В. Холмакова, викладач

(Київський національний університет культури і мистецтв) margaritasantedyahoo.com ORCID: 0000-0002-9340-6012
\end{abstract}

\title{
ЛАТИНСЬКІ ЗАПОЗИЧЕННЯ В АНГЛІЙСЬКІЙ ТА УКРАЇНСЬКИХ МОВАХ
}

Статтю присвячено функціонуванню латинських запозичень в англійській та украйнських мовах. Актуальність вивчення цісї теми очевидна, але все ж таки деякі аспекти ще не вивчені. Між усіма запозиченнями з італійської, грецької, французької, скандинавської, російської, німецької, іспанської та інших мов найбільший вплив на англійську та украӥнську мову мають латинські запозичення. Латинські

запозичення мають беззаперечне значення в лексичній структурі: таргетована мова буквально складається з коренів, суфіксів і префіксів (дериваційних морфем). Тому це питання особливо актуально для тих, хто вивчає іноземну мову, це завжди ціккаво $і$ завдяки незліченному матеріалу для розгляду та

дослідження, буде постійно генерувати нові теми для дебатів та дискусій. Але для вчених, щчо працюють у галузі лексикології, щуе багато питань потребують вирішення. Вчених иікавить не тільки те, як і чому прийшло запозичене слово, але як воно засвоюється в мові, як змінювався зміст, а зміни призводили до його появи в прийнятому словнику його мови.

Ключові слова: запозичення, мова, функиіонування, слова, розвиток.

Аналіз останніх досліджень та публікацій. Відомий російський мовознавець ХІХ століття Олександр Потебня думав, що не варто запитувати, як і від кого запозичені слова. Але ця точка зору не стала поширеною в той час і не знайшла відповіді. Олександр Потебня звернув увагу на творчий елемент у процесі запозичення. "Запозичення, - сказав він, - так зважайте на те, щоб мати можливість принести в скарбницю людської культури більше, ніж вона отримує" [1: 35-36].

Такий підхід до питання запозичення розкриває закони, що регулюють розвиток лексики, пояснюють явища, що відбуваються в ній, і визначають їх причини, виявляють зв'язки між історією окремих слів, історією, мовою та історією народу. Мови ніколи не віддають слова, які вони запозичують, вони зберігають їх назавжди, або поки вони не застаріють. Запозичені слова начебто занурюються в словниковий запас, поки всі не забудуть, що вони коли-небудь звучали іноземно. Вони повністю поглинаються нашою мовою і стають рідними. Але лише деякі слова приносять 3 собою якийсь граматичний багаж зі своєї мови, і вони не асимілюються так добре. Найяскравіший приклад формування множини [2: 17-20].

Метою дослідження є виявлення особливостей латинських запозичень в англійській та українській мовах.

Теоретична цінність дослідження - запозичений аспект, ступінь засвоєння; вивчаються запозичення 3 латинської мови.

Практична цінність дослідження: матеріал даної статті може бути використаний на лекціях, практичних курсах і семінарах з вивчення латинських запозичень.

Виклад основного матеріалу. Словник сучасної англійської мови - це комплексне поєднання різних елементів, що накладаються один на одного протягом всієї історії мови і вступають у різні відносини один $з$ одним. Англійська структура словника змінюється як з часом, так і з будь-якою мовою. Багато слів, які раніше використовувалися, зникли з сучасної мови, тому що змінилися умови життя, або тому, що їх місце займали інші слова, які використовувалися. Правда, англійська лексика, яка є однією 3 найширших серед світових мов, містить величезну кількість слів іноземного походження. Пояснення до цього слід шукати в історії мови, яка тісно пов'язана з історією народної мови. Щоб краще зрозуміти проблему, необхідно пройти короткий огляд історичних фактів, що стосуються різних епох [3: 142-146].

Запозичення словникового запасу може здійснюватися шляхом усних і письмових способів. У випадку запозичення з усним шляхом, слова можуть швидше повністю засвоюватися в мові. Слова, запозичені зі способом написання, зберігають свої фонетичні, орфографічні та граматичні особливості.

Запозичення може бути прямим і через посередницьку мову. Мовою посередником були, наприклад, латинська (через латину англійською мовою отримано багато грецьких слів) і французька (з якої було запозичено багато латинських слів). 
Існує декілька груп: фонетичні запозичення, перекладацькі запозичення, семантичні запозичення, морфемні запозичення. Фонетичні запозичення $\epsilon$ найбільш характерними для всіх мов. Слова запозичують правопис, вимову і значення. Потім вони проходять асиміляцію, кожен звук запозиченої мови. У деяких випадках змінюється написання. Структуру слова також можна змінити. На положення наголосу дуже часто впливає фонетична система запозичувальної мови. Парадигма слова, а іноді і значення запозиченого слова також змінюються. Такі слова, як: labor, travel, table, chair, people фонетичні запозичення з французької; apparatchic, nomenclature, sputnik є запозичення з російської; bank, soprano, duet - фонетичні запозичення з італійської мови [4: 114-117].

Перекладацькі запозичення - дослівний переклад деяких іноземних словосполучень. У таких випадках поняття запозичене з іноземної мови, але воно виражається рідними лексичними одиницями, "to take the bull by the horns" (латинська). Деякі перекладацькі запозичення з'явилися в англійській мові 3 латинської мови вже в староанглійському періоді, наприклад, Sunday (solis dies) [1: 154-166].

Семантичні запозичення - запозичене нове значення одиниці, що існує в мові. Це може статися, коли ми маємо дві споріднені мови, які мають спільні слова з різними значеннями.

Морфемні запозичення - це запозичення афіксів, які відбуваються в мові, коли багато слів 3 однаковими афіксами запозичені з однієї мови в іншу, так, що морфемна структура запозичених слів стає звичною для людей, що говорять мовою запозичення.

У сучасній лінгвістиці виділяються внутрішні і зовнішні причини запозичення. Зовнішні причини включають контакти між народами, які визначаються як близькість географічного положення, так i потреби спільного вирішення відповідних політичних, економічних питань, культурного та наукового обміну. Суто мовні причини для запозичення:

а) необхідність доповнювати або навіть створювати специфічні лексико-семантичні групи, які представлені або відсутні на певному етапі мови, що займає;

b) необхідність семантичного обмеження конкретних слів, усунення його неоднозначності;

c) більшою мірою термінологічної ясності запозичення слів, які відбувалися в мові джерела, у порівнянні з існуючим аналогом мовою одержувача.

Термін "запозичення" використовується в лінгвістичній літературі у двох сенсах. У зв'язку з теорією мовного контакту, взаємодії мови, запозиченням називається один із способів збагатити словниковий запас мови. Вона також вказує на процес введення та адаптації запозичених жетонів і результат цього процесу - запозичене слово token. Також слово, що складається з елементів, запозичених 3 різних мов або елементів, частково запозичених і частково оригінальних слів, називаються гібридами (beautiful - fr. корінь + Eng. суфікс).

Основні проблеми етимології та запозичених слів, які стосуються англійської мови, всебічно i послідовно розглядаються. Вона розглядає ці питання переважно з точки зору одноманітності слова, що відображає його методологічний підхід до теорії слів [5: 456-485].

Розглянемо іноземні запозичені слова, фонетичні та граматичні, розроблені за типом іноземної мови. Ti, хто йде шляхом адаптації до мови одержувача, змінюючи звукове оформлення, знижуючись через виникнення перегинів, виявляючи дію словотворчої діяльності і навіть формуючи нові лексикосемантичні варіації, повністю вивчають мову. Тема гібридів вже була розглянута в розділі про деривації [6: 106-107].

Деякі слова, які походять з іноземної мови є проміжними між іноземними словами і повністю засвоєними запозиченнями. По-перше, запозичення слів 3 іноземної мови можна використовувати в текстах цільової мови як іноземні включення, зберігаючи при цьому свою зовнішню структуру, і якщо вони (як правило, є проявом дотримання модної тенденції) починають більш-менш регулярно використовуватися, то вони називаються барбаризмами.

Оскільки запозичення є результатом довгої історії взаємодії мов та їх змішування, то креслення займало значне місце в лексиконі багатьох мов. Посилена взаємодія, як зростаюча роль культурноекономічних зв'язків між народами, а також глобалізація призводить до певного шару запозичень, які називаються інтернаціоналізованими словами (інтернаціоналізм). Досліджено взаємодію мовних та позамовних, тобто політичних, економічних та культурних факторів [7: 178-179]. В українській мові прикладами таких слів є комітет, проект, інфляція.

Гетерогенний словник будь-якої мови дуже різноманітний як з генетичної, так і з функціональної $\mathrm{i}$ структурної точки зору. Однією з найбільших груп європейських мов є запозичення з латинської мови, що свідчить про силу впливу давньої цивілізації на формування нових культур.

Для вимірювання великих відстаней римляни використовували одиницю довжини, що дорівнює тисячі кроків (1,5 км). Ця міра була прийнята стародавніми британцями разом з її назвою.

Перший шар також включає слова, які пізніше були запозичені англосаксами на Британських островах. Ці слова пов'язані, головним чином, з будівельними прийомами стародавніх римлян, сліди яких англо-саксонці виявили у Великобританії.

Нижче наведені декілька прикладів: 


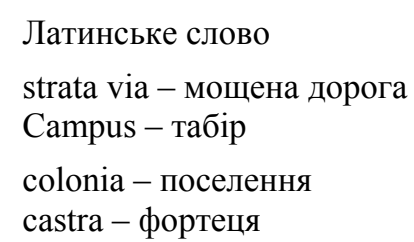

\section{Латинське слово}

strata via - мощена дорога

colonia - поселення

castra - фортеця

\author{
Сучасне англійське \\ street [st'ri:t] - вулиця \\ camp ['kæmp] \\ colony ['kכlənI] - колонія \\ castle
}

1. Другий шар.

Другий шар латинських запозичень, пов'язаних 3 християнством, принесений римськими проповідниками, привернув язичників англосаксів до нової віри. Мовна церковна служба велася латинською мовою, тому римська мова пронизала багато латинських слів з релігійним змістом. Більшість цих слів спочатку не були латинськими, а перейшли на латинську з грецької, оскільки християнство розвивалося у східній частині Римської імперії. Християнські книги були перекладені на латинську мову.

Нижче декілька слів 3 того періоду:

\begin{tabular}{|c|c|}
\hline Латинське слово & Сучасне англійське \\
\hline Episcopus - єпископ & bishop ['bI $\left.\int \partial p\right]$ \\
\hline $\begin{array}{l}\text { Presbyter - священик } \\
\text { Monachus - монах }\end{array}$ & $\begin{array}{l}\text { priest ['prI:st] } \\
\text { monk [monk] }\end{array}$ \\
\hline $\begin{array}{l}\text { Scrinium - священна гробница } \\
\text { Candela - свічка }\end{array}$ & $\begin{array}{l}\text { shrine ['JraIn] } \\
\text { candle ['kændl] }\end{array}$ \\
\hline Monasterium - монастир & mynster (minster) ['mInstə] \\
\hline
\end{tabular}

Прийняття християнства і діяльність проповідників мали сильний вплив на всю культуру англосаксів. Введено латинський алфавіт. Були чернечі школи, літературні твори на латині і т.ін. Було запозичено багато слів, що свідчать про розширення світогляду англосаксів.

Нижче наведено декілька прикладів:

$\begin{array}{ll}\text { Латинське слово } & \text { Сучасне англійське } \\ \text { schola - школа } & \text { school ['sku:l] } \\ \text { magister - вчитель } & \text { schoolmaster ['sku:lm^stə] } \\ \text { rosa - роза } & \text { rose ['rouz] } \\ \text { palma - пальма } & \text { palma ['pa:m] } \\ \text { phoenix - фенікс } & \text { fenix [feniks] } \\ \text { leo - лев } & \text { lion ['laIən] } \\ \text { pardus - леопард } & \text { leopard ['lepəd] }\end{array}$

2. Третій шар.

На зміну середньовіччя прийшло Відродження, яке характеризується бурхливим розвитком науки і техніки, безпрецедентним розквітом літератури i мистецтва, винаходом друкарства, великими географічними відкриттями, успіхами матеріалістичної філософії проти релігійних догматів і панування Церква.

У цей період англійська мова запозичила багато слів 3 класичних мов. Від попередніх вони різко відрізнялися його характером: це слова, які зазвичай досліджуються. Вони проникли в мову, написавши, через літературу, твори вчених, які сприяли максимальному збереженню латинської форми слова.

Наприклад:

\begin{tabular}{|c|c|c|}
\hline animal & - в англійській мові [ 'ænIməl] & тварина \\
\hline formula & - в англійській мові [fว:mjulə] & формула \\
\hline $\begin{array}{l}\text { inertia } \\
\text { maximum }\end{array}$ & 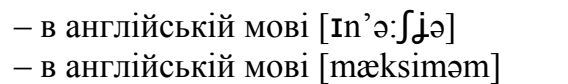 & $\begin{array}{l}\text { інерція } \\
\text { максимум }\end{array}$ \\
\hline $\begin{array}{l}\text { minimum } \\
\text { memorandum }\end{array}$ & $\begin{array}{l}\text { - в англійській мові [mInIməm] } \\
\text { - в англійській мові [,memə’rændum] }\end{array}$ & $\begin{array}{l}\text { мінімум } \\
\text { меморандум }\end{array}$ \\
\hline veto & - в англійській мові [ 'vI:tou] & вето \\
\hline alibi & - в англійській мові [ 'ælıbaI] & аліби \\
\hline autograph & - в англійській мові [‘ว:təgrəf] & автограф \\
\hline excursion & - в англійській мові [ıks’kə:[n] & екскурсія \\
\hline
\end{tabular}

Українська мова належить до східної групи слов'янської гілки індоєвропейської сім'ї мов. Останнім 
часом лексичні структури активно запозичені з англійської мови. Загальний розвиток мови обумовлений внутрішніми ресурсами - нові слова створюються на основі існуючих слів.

Запозичення 3 різних мов відбувалися в різний час. Багато запозичених слів настільки знайомі нам, що ми не відчуваємо чужого походження (панчохи, иукор, кавун); інші навіть не набули здатності змінювати закони української граматики (меню, тріо, кашне). Навіть деякі займенники і сполучні слова були запозичені, що буває дуже рідко, наприклад: same, both, till, for, though та займенникові форми з 'th': they, them, their [8: 15-17].

У XV-XVII ст. латинська мова була популярна в Західній Європі, яка була мовою Церкви і науки, а в XV ст. ця мова почала вивчатися в українських школах. Зокрема, у Києво-Могилянській академії та Братській школі, латинська мова була однією з головних тем. Популяризація латинської мови також сприяла перекладам творів грецьких філософів, таких як Аристотель, Платон і Ксенофонт, чиї ідеї знайшли готові відповіді у свідомості і серцях прогресивних людей того часу. Хоча пізніше вона втратила свої позиції, але як і грецька мова вона була джерелом постачання до європейських мов, включаючи українську [9: 343-351].

Латинські запозичення використовуються в основному в термінології в різних дисциплінах:

- Наукові, технологічні терміни та терміни з мистецтвознавства: reaction (реакція), radius (padiyc), circus (цирк), hитог (гумор), literature (література), ріапо (піаніно);

- Політичні, юридичні, медичні терміни: constitution (конституція), communismus (комунізм), socialismus (соиіалізм), respublica (республіка), statutum (cmamym), jurisperitus (юрист), patronus (адвокат), notarius (нотаріус), propaganda (пропаганда), angina (ангіна), sanitarius (санітар), depression (депресія), defectum (дефект), and tubeculosis (туберкульоз);

- Шкільні терміни: auditorium (аудиторія), stipendium (стипендія), rector (ректор), decanus (декан), docens (доцент), ехатеп (екзамен), ипiversitas (університет), studiosus (студент), conspectus (конспект), scola (лекція), facultas (факультет);

- $\quad$ Власні імена: Віктор, Віталій, Юлія та інші.

Висновки та перспективи подальших досліджень. Запозичення слів 3 інших мов характерно для англійської мови протягом всієї ії історії. Більше двох третин англійської лексики є запозиченнями. В основному, це слова романського походження (латинська, французька, італійська та іспанська). Запозичені слова відрізняються від вітчизняних своєю фонетичною структурою, морфологічною структурою, а також граматичними формами. Також характерно, що запозичення семантично невмотивовані.

Очевидно, що англійська історія дуже багата різними типами контактів з іншими країнами, тому вона дуже багата запозиченнями. Римське вторгнення, прийняття християнства, скандинавські і норманські завоювання Британських островів, розвиток британського колоніалізму і торговельних культурних зв'язків сприяли великому зростанню англійської лексики. Більшість цих запозичень повністю засвоюється англійською мовою в їхній вимові, граматиці та орфографії, і її важко відрізнити від рідних слів.

Англійська мова продовжує приймати іноземні слова, але тепер кількість запозичень не така велика, як це було раніше.

Таким чином, запозичення класифікуються за різними критеріями:

а) за аспектом запозичення; б) за рівнем асиміляції; в) за запозиченою мовою.

У цій класифікації були описані лише основні мови, з яких були запозичені слова англійською мовою: латинська, французька, італійська, іспанська, німецька та російська. Як ми вже згадували вище, етимологічно словниковий запас англійської мови складається з двох груп - рідних слів і запозичених слів. Етимологічний лінгвістичний аналіз показав, що запозичений запас слів більше, ніж рідний запас слів. До рідних слів ми включаємо слова 3 загальної німецької мови та 3 індоєвропейських запасів. Запозичені слова - це слова, взяті з інших мов. Багато лінгвістів вважають, що іноземний вплив грає найважливішу роль в історії англійської мови. Але граматична і фонетичні системи дуже стабільні (незмінні) і часто не піддаються впливу інших мов. Крім того, коли ми говоримо про роль вітчизняних і запозичених слів в англійській мові, ми не повинні враховувати лише товщину їх семантичного, стилістичного характеру, їх здатності до словотворчості, частотного значення, збиральності (валентності) i продуктивності їхніх словотворчих моделей. Якщо підходити до вивчення ролі вітчизняних i запозичених слів з цієї точки зору, то ми бачимо, хоча рідні слова нечисленні, вони грають важливу роль в англійській мові. Вони мають високочастотне значення, велику словотворчу силу, широку збіжність, багато смислів і стилістично нейтральні. Майже всі слова вітчизняного походження належать до дуже важливих семантичних груп.

Запозичення лексики - взаємозв'язок націй на основі економічних, політичних, наукових і культурних зв'язків. Яскравим прикладом цього є численні латинські запозичення англійською мовою. 
Піддаючись впливу різних морфологічних, лексичних і фонетичних змін, багато кредитів втратили свою французьку форму і не сприймаються як іноземне слово. Шлях, який залучав їх повне засвоєння мови, був багатоступінчастим.

На нашу думку, нам вдалося вивчити функціонування латинських запозичень в англійській та українській мовах. Ми обговорювали можливі шляхи перекладу латинських слів англійською та українською мовами, розглядали різні види запозичень.

Незважаючи на деякі засоби англійської лексики, запозичені 3 інших мов, англійська мова, як правило, не постраждала від великого припливу іноземних елементів. Навпаки, іiі лексика безперечно збагатилася. Це стало можливим завдяки тому, що вона вивчила елементи іноземної мови, які ввібрали в себе всі цінні і необхідні, знижуючи в подальшому розвиток всіх випадкових.

\section{СПИСОК ВИКОРИСТАНИХ ДЖЕРЕЛ ТА ЛІТЕРАТУРИ}

1. Потебня О. О. Актуальні питання мови та культури : [збірник наукових праць] / О.О.Потебня. - Київ, 2004. $-368 \mathrm{c}$.

2. Антрушина Г. Б. Лексикология английского языка / Г. Б. Антрушина, О. В. Афанасьева, Н. Н. Морозова. М. : Дрофа, 1999. - С. 44-78.

3. Арнольд И. В. Лексикология современного английского язика : [учебное пособие] / И. В. Арнольд. - М. : Изд-во лит-ры на иностранных языках, 1959. - 351 с.

4. Bryson B. Made in America: An Informal History of the English Language in the United States / Bill Bryson. N.Y. : William Morrow and Co., 1995. - 417 p.

5. Bryson Bill Mother Tongue : English and How It Got That Way / Bill Bryson. - N.Y.; Avon Books, 1990. - 602 p.

6. Bolton W. F. A Living Language: The History and Structure of English / W. F. Bolton. - N. Y. : Random House, 1982.- $146 \mathrm{p}$.

7. Cran William, MacNeil Robert The story of English / William Cran, Robert Macneil. - N.Y. : Elizabeth Sifton, 1986. $-346 \mathrm{p}$.

8. Reznik R. V. A History of the English Language / R. V. Reznik, T. S. Sorokina, I. V. Reznik. - M. : Nauka, 2001. $-496 \mathrm{p}$.

9. Scott Julia Arabic Culture and Medieval European Literature / Julia Scott / Journal of the American Oriental Society, 1991. $-564 \mathrm{p}$.

10. Haugen Einar The Analysis of Linguistic Borrowings / Einar Haugen. - Vol. 26, 1950. - 254 p.

\section{REFERENCES (TRANSLATED \& TRANSLITERATED)}

1. Potebnia O. O. Aktual'ni pytannia movy ta kul'tury [Topical Issues of Language and Culture] : [zbirnyk naukovykh prats'] / O. O. Potebnia. - Kyiv, 2004. - 368 p.

2. Antrushyna H. B. Leksikolohiia angliiskogo yazyka [English Lexicology] / H. B. Antrushyna, O. V. Afanasieva, N. N. Morozova. - M. : Drofa, 1999. - Pp. 44-78.

3. Arnold I. V. Leksikolohiia sovremennoho angliiskogo yazyka [Modern English Lexicology]: [uchebnoie posobiie] / I. V. Arnold. - M. : Izd-vo lit-ry na inostrannykh yazukakh, 1959. - 351 p.

4. Bryson B. Made in America: An Informal History of the English Language in the United States / Bill Bryson. N.Y. : William Morrow and Co., 1995. - 417 p.

5. Bryson Bill Mother Tongue : English and How It Got That Way / Bill Bryson. - N.Y.; Avon Books, 1990. -602 p.

6. Bolton W. F. A Living Language: The History and Structure of English / W. F. Bolton. - N. Y. : Random House, 1982.- $146 \mathrm{p}$.

7. Cran William, MacNeil Robert The story of English / William Cran, Robert Macneil. - N.Y. : Elizabeth Sifton, 1986. $-346 \mathrm{p}$.

8. Reznik R. V. A History of the English Language / R. V. Reznik, T. S. Sorokina, I. V. Reznik. - M. : Nauka, 2001. $-496 \mathrm{p}$.

9. Scott Julia Arabic Culture and Medieval European Literature / Julia Scott / Journal of the American Oriental Society, 1991. $-564 \mathrm{p}$.

10. Haugen Einar The Analysis of Linguistic Borrowings / Einar Haugen. - Vol. 26, 1950. - 254 p.

\section{Кузнецова А. С., Холмакова Ю. В. Латинские заимствования в английском и украинском языках.}

Статья посвящена функиионированию латинских заимствований в английском и украинском языках. Актуальность изучения этой темы очевидна, но все же некоторые аспекты еще не изучены. Между всеми заимствованиями из итальянского, греческого, франиузского, скандинавского, русского, немецкого, испанского и других языков наибольшее влияние на английский и украинский язык имеют латинские заимствования. Латинские заимствования имеют неоспоримое значение в лексической структуре: таргетированная речь буквально состоит из корней, суффиксов и префиксов (деривачионных морфем).

Поэтому этот вопрос особенно актуальный для тех, кто изучает иностранный язык, это всегда интересно и благодаря бесчисленному материалу для рассмотрения и исследования, будет постоянно генерировать новые темы для дебатов и дискуссий. Но для ученых, работающих в области лексикологии, есть еще много вопросов требующих рещения. Ученых интересует не только то, как и 
почему пришло заимствованное слово, но как оно усваивается в языке, как менялся смысл, а изменения приводили к его появлению в принятом словаре этого языка.

Ключевые слова: заимствования, язык, функционирования, слова, развитие.

\section{Kuznietsova A. S., Kholmakova Yu. V. Latin Borrowings in English and Ukrainian Languages.}

This term paper is devoted to the functioning of Latin borrowings in English and Ukrainian languages. The topicality in learning Latin borrowing in English and Ukrainian languages is obvious. Some aspects of this theme have not learnt to the end yet. Between all borrowings from Italian, Greek, French, Scandinavian,

Russian, German, Spanish and other languages, Latin borrowings have the biggest influence on English and

Ukrainian language." We don't just borrow on occasion, English has pursued other languages down alleyways to beat them unconscious and rifle their pockets for new vocabulary".

English borrowings have undeniable importance in the lexical structure: the target language is literally made out of the roots, suffixes and prefixes (derivational morphemes). Therefore, this issue is particularly relevant for those who learning a foreign language, it is always interesting and thanks to countless material for consideration and research, will constantly generate new topics for debates and discussions. However, for scientists working in the field of lexicology, still many issues need resolution. Scientists are interested in not only how and why came borrowed word, but as it is assimilated in the language, as it yielded to the grammatical structure and phonetic rules as changed its meaning and changes resulted in his appearance in the accepted vocabulary of his language.

Key words: borrowings, language, functioning, words, development. 